\title{
Water Quality in the Central Reach of the Ina River (Western Pomerania, Poland)
}

\author{
Arkadiusz Nędzarek*, Małgorzata Bonisławska, Agnieszka Tórz, \\ Anna Gajek, Marlena Socha, Filip Bronisław Harasimiuk
}

Department of Water Sozology, West Pomeranian University of Technology in Szczecin,

K. Królewicza 4, 71-550 Szczecin, Poland

Received: 23 April 2014

Accepted: 8 July 2014

\begin{abstract}
Our paper presents a study on the middle reaches of the Ina River. Select physical and chemical indicators were analyzed in order to evaluate water quality. It was determined that the studied river was subjected to strong anthropopressure, and factors declassifying river water included $\mathrm{COD}_{\mathrm{Cr}}, \mathrm{TP}$, general hardness, and alcalinity. A high level of biogenic elements was additionally increased by pollution discharged to the river in the proximity of a factory specializing in agricultural production and processing food and agricultural produce near the town of Stargard Szczeciński. The process of self-purification was noted, which can be considered as a factor modifying changes and dynamics of nitrogen and phosphorus in the studied river, leading to an internal enrichment with biogenic elements. Those processes were multi-directional as confirmed by PCA analysis, where component 1 accounted for just $36.7 \%$ of the total variance, and the total variance exceeding $90.0 \%$ was only noted for 7 components.
\end{abstract}

Keywords: water pollution, nutrients, organic matter, Ina River

\section{Introduction}

Physical and chemical properties of river water are subject to both temporal and spatial changes and depend mainly on the environment of the catchment area and its condition. Continuity of ecological processes and the gradient character of river zones (so-called river continuum) are characteristic features of rivers. The flow of matter and energy is one-directional, the same as the direction of the river flow, and a gradual increase of dissolved substances concentrations is natural $[1,2]$. Human activity is responsible for deviations from a model water flow because geochemical cycles of carbon, nitrogen, and phosphorus undergo significant modifications [3]. The most important anthropogenic factors influencing river ecosystems include agriculture, industry, and urbanization. The supply of pollution from these sources affects water quality in the river and its biocenosis. It is especially damaging for small watercourses that constitute environmentally valuable ecosystems. Therefore, constant monitoring of water quality, providing the possibility to trace the sources of pollution, is an important element of natural environment protection.

In light of the above, the objective of the present study was to analyze and assess select physico-chemical indicators of water in the middle reaches of the Ina River and point out those that determine its quality. The analysis of horizontal variability of the studied water quality indicators allowed for assessing purity of the examined stretch of the Ina River and identifying the sources of pollution.

*e-mail: arkadiusz.nedzarek@zut.edu.pl 


\section{Material and Methods}

Study Area

The Ina River is a right tributary of the Oder in northwestern Poland in West Pomeranian Voivodeship. The river is $126 \mathrm{~km}$ long and has a catchment area of 2,151 km². Its most important tributaries are: Krapiel, Mała Ina, Stobnica, and Reczyca. The Ina and its catchment area constitute an environmentally valuable area being the habitat of rare species of the Cyclostomata, such as: sea lamprey (Petromyzon marines), European river lamprey (Lampetra fluviatilis), and European brook lamprey (Lampetra planeri), as well as valuable fish species, such as: Atlantic salmon (Salmo salar L.), sea trout (Salmo trutta m. trutta L.), brown trout (Salmo trutta trutta m. fario L.), vimba (Vimba vimba L.), asp (Aspius aspius L.), eel (Anguilla anguilla L.), gudgeon (Gobio gobio L.), white-finned gudgeon (Romanogobio albipinnatus Lukasch), belica (Leucaspius delineatus L.), spined loach (Cobitis taenia L.), loach (Misgurnus fossilis L.), stone loach (Barbatula barbatula L.), and bullhead (Cottus gobio L.). The Ina River and its tributaries can constitute a basis for natural reproduction of migratory salmonid fish [4]. Although only small fragments of the Ina have a rocky and gravelly bottom providing favourable conditions for the reproduction of salmonid fish, as many as 60 redds were found in the riverbed [5]. Simultaneously, the authors reported heightened values of 5 out of 14 studied water quality indicators $[4,5]$. In 2008-09 water quality in the Ina River was classified as good and less than good, whereas in 2010-11 it was classified as bad $[6,7]$.

The following protected areas are part of the network NATURA 2000, meant to preserve certain types of habitats as well as valuable and endangered species situated in the Ina catchment area: Ina Valley near Recz (Polish: Dolina Iny koło Recza) (PLH320004), Krapiel Valley (Dolina Krąpieli) (PLH320005), Ina Valley near Goleniów (Goleniowska Dolina Iny) (pltmp541), Goleniów Refuge (Ostoja Goleniowska) (PLH320013), Ińsko Lakeland (Pojezierze Ińskie) (PLH320067), and Goleniów Forest (Puszcza Goleniowska) (PLB320012).
The presented hydrochemical study on the middle reaches of the Ina was conducted from November 2011 to July 2012. Water samples were collected once a month according to methodology recommended by [8], from four research sites:

1) A site located near the mouths of the rivers: Reczyca

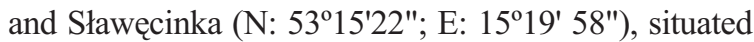
in the NATURA 2000 protected area of the Ina Valley near Recz; width 8.0 m, depth 1.0-2.0 m

2) A site located below grasslands and meadows belonging to a factory specializing in agricultural production and processing food and agricultural produce $(\mathrm{N}$ : $53^{\circ} 18^{\prime} 57^{\prime \prime}$ E: $\left.15^{\circ} 03^{\prime} 28^{\prime \prime}\right)$; width $14.0 \mathrm{~m}$, depth $1.5-2.0 \mathrm{~m}$

3) A site located in the central part of the town of Stargard Szczeciński (N: 5320'36"; E: 1502'54"); width $15.0 \mathrm{~m}$, depth $1.0-1.5 \mathrm{~m}$

4) A site located below the zone of influence of Stargard Szczeciński, at a distance that assures complete mixing of river water with released storm waters and wastewater discharged from the municipal water treatment

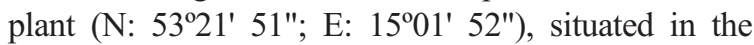
NATURA 2000 protected area of the Ina Valley near Goleniów"); width 15.0 m, depth 1.5-2.0 m (Fig. 1).

Water samples necessary for analyses of hydrochemical parameters were collected once a month from the superficial layer, at a depth of $50 \mathrm{~cm}$. The analyses of hydrochemical indicators were conducted according to methodology recommended by [8]. Absorbances were measured at the recommended wavelengths in a Spectroquant Pharo 300 Merck spectrophotometer. Nitrite nitrogen was assayed with sulphanyl acid $(\lambda=543 \mathrm{~nm})$. Nitrate nitrogen was determined as nitrites after reduction on a $\mathrm{Cu}-\mathrm{Cd}$ column. Ammonium nitrogen was assayed with indophenol blue $(\lambda=630 \mathrm{~nm})$. Total reactive phosphorus (TRP) was assayed using the molybdenate technique with ascorbic acid as a reducer $(\lambda=882 \mathrm{~nm})$. Total phosphorus (TP), after mineralization with potassium hypersulphate was assayed as TRP. Phenanthroline $(\lambda=510 \mathrm{~nm})$ was used to determine total iron. Biological oxygen demand $\left(\mathrm{BOD}_{5}\right)$ was determined by a direct method after five-day incubation of the samples with no access to light at a constant temperature $20^{\circ} \mathrm{C}$. Chemical oxygen demand $\left(\mathrm{COD}_{\mathrm{Cr}}\right)\left[\mathrm{mgO}_{2} \cdot \mathrm{dm}^{-3}\right]$ was deter-

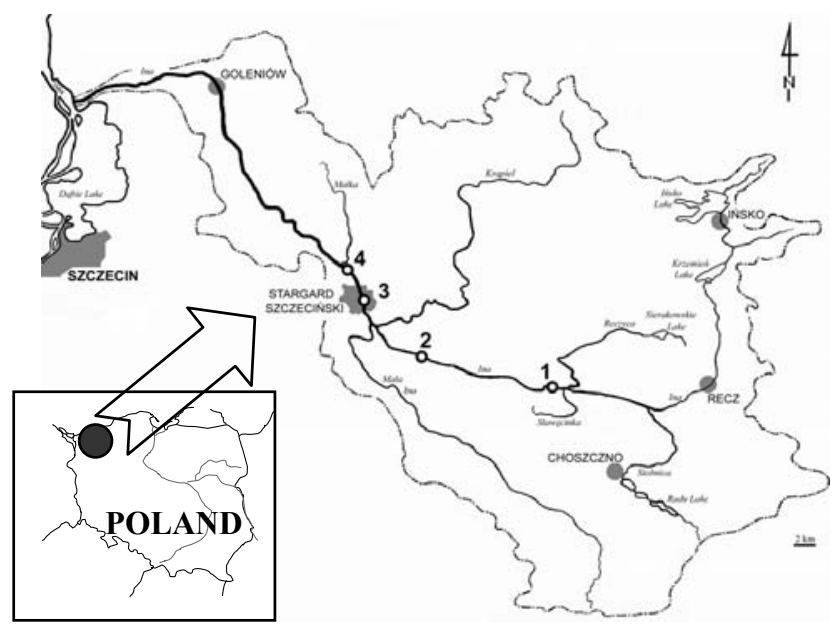

Fig. 1. Catchment area of the Ina River and location of water sampling sites (1-4) during the conducted studies. 


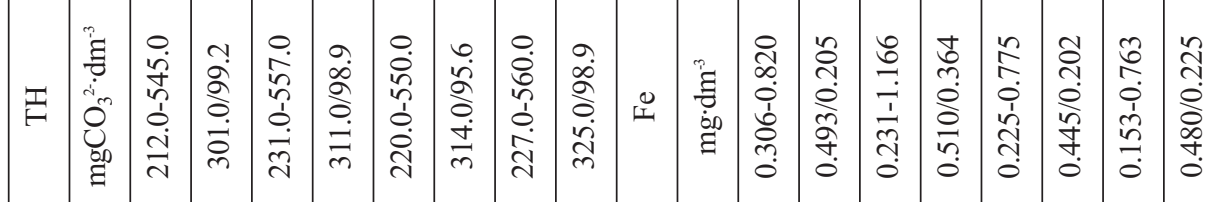

गे

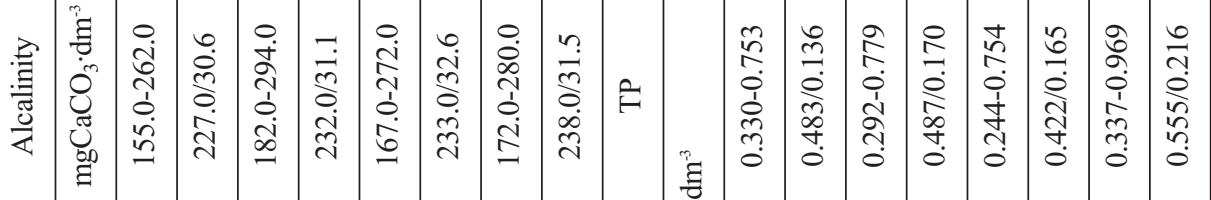

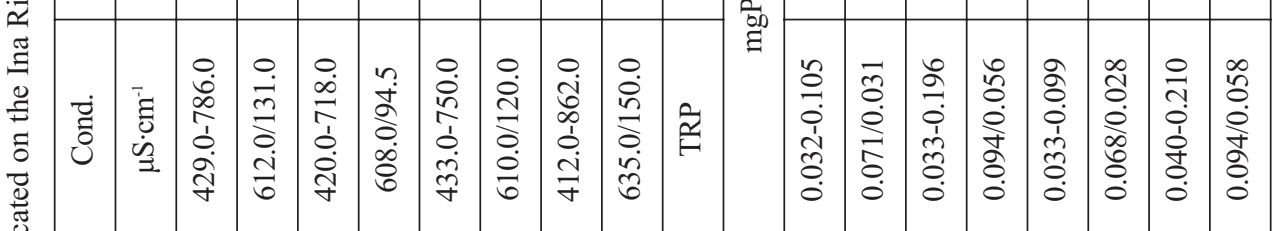

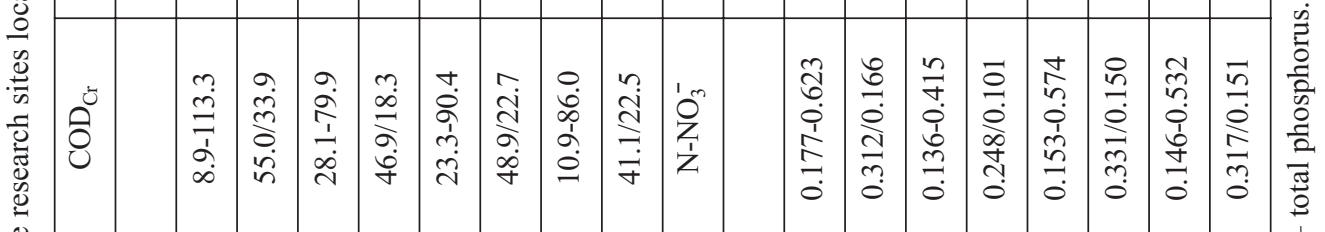

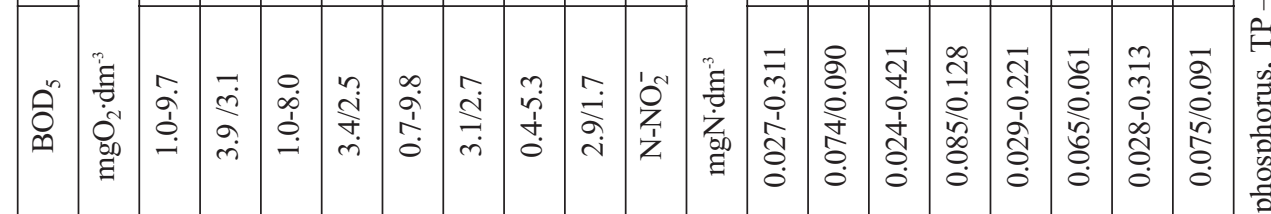

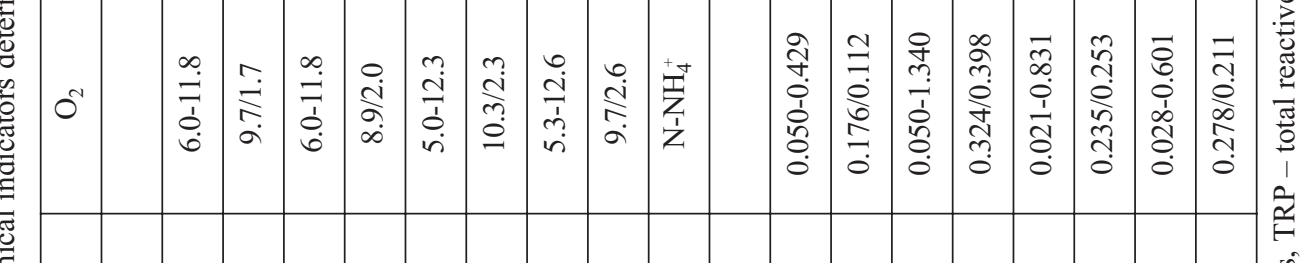

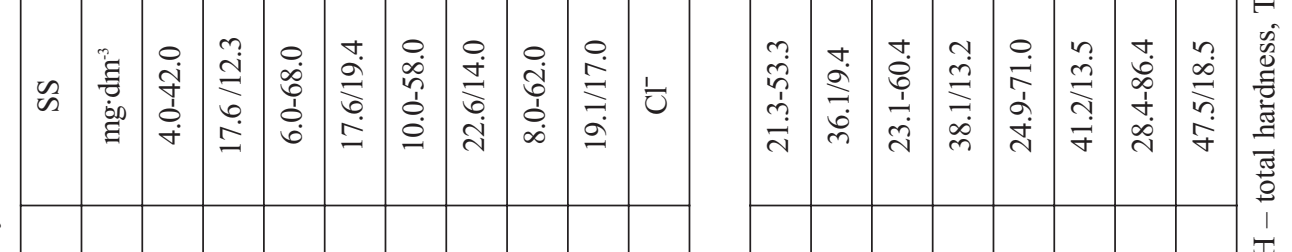

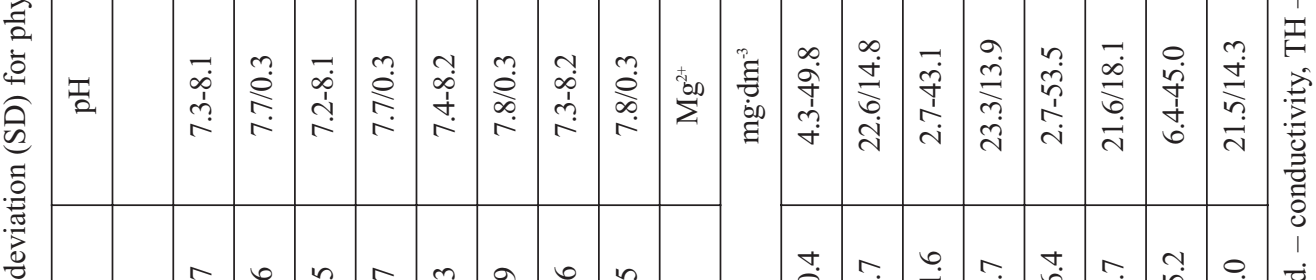

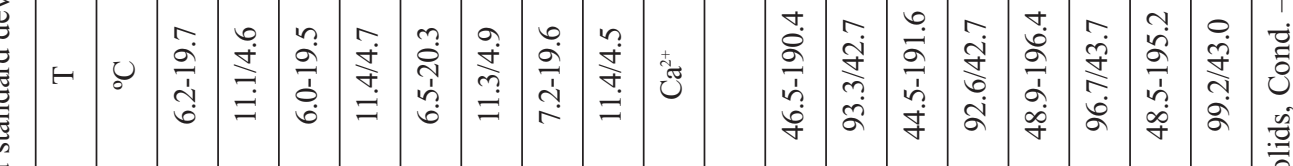

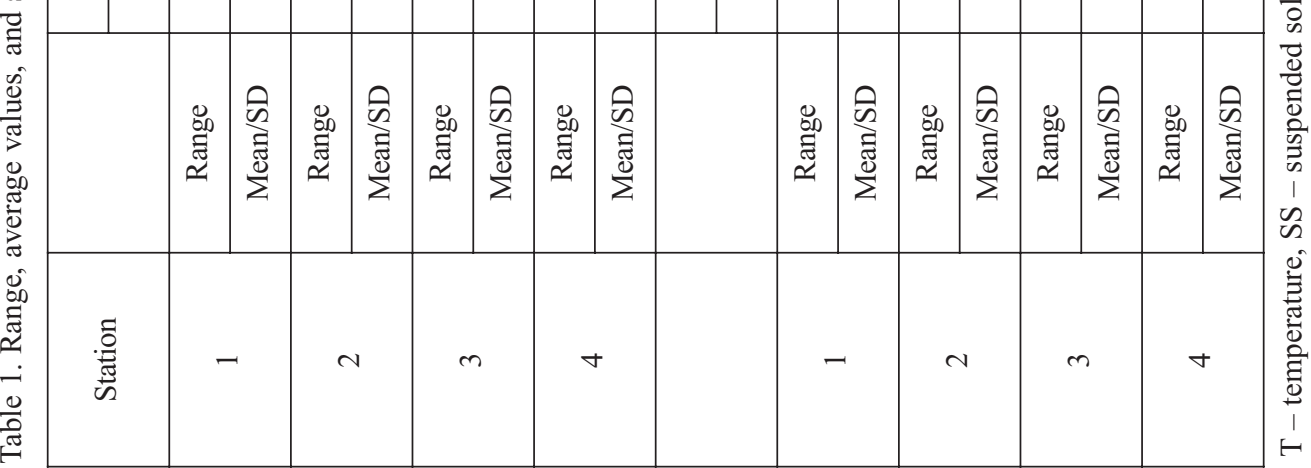


mined by the dichromate method. Dissolved oxygen (DO) was determined by Winkler method. Total hardness, $\mathrm{Ca}^{2+}$ and $\mathrm{Mg}^{2+}$ were determined using the complexometric titration method. Alcalinity was determined with $0.1 \mathrm{~N} \mathrm{HCl}$, using methyl orange as an indicator. Chloride ions were determined by Mohr's method. Total suspension was determined by weighing. Such water parameters as water temperature, conductivity (Elmetron CC-101 conductivity mater), and $\mathrm{pH}$ (Elmetron $\mathrm{CP}-103$ waterproof $\mathrm{pH}$-meter) were measured directly at sampling.

Study results were analyzed statistically using Statistica 10.1 software (StatSoft Inc. 2013). Principal component analysis (PCA) was conducted for the purposes of dimensionality reduction and feature integration. Pearson's linear correlation coefficient was applied in order to analyze relationships among the studied physico-chemical indicators, with confidence coefficient of $\alpha=0.05$.

Obtained values of water quality indicators were assessed according to the requirements specified in the Directive of the Minister of Environment of 9 November 2011 on classification of uniform parts of surface waters and on environmental quality standards for priority substances [9].

\section{Results}

Average values and ranges of tested indicators for respective research sites located on the Ina River are given in Table 1. Average values of water temperature, $\mathrm{pH}$, total suspension, and DO for the whole study period amounted to $11.3^{\circ} \mathrm{C}, 7.7,19.2 \mathrm{mg} \cdot \mathrm{dm}^{-3}$, and $9.6 \mathrm{mgO}_{2} \cdot \mathrm{dm}^{-3}$, respectively. Average organic matter content in water, characterized by $\mathrm{BOD}_{5}$ and $\mathrm{COD}_{\mathrm{Cr}}$, amounted to 3.3 and 48.0 $\mathrm{mgO}_{2} \cdot \mathrm{dm}^{-3}$, respectively. Average concentrations of major ions: $\mathrm{Ca}^{2+}, \mathrm{Mg}^{2+}$, and $\mathrm{Cl}^{-}$amounted to 95.5, 22.2, and 43.5 $\mathrm{mg} \cdot \mathrm{dm}^{-3}$, respectively. The values of conductivity, alcalinity, and total hardness amounted to $616.0 \mu \mathrm{S} \cdot \mathrm{cm}^{-1}, 233.0$ $\mathrm{mgCaCO}_{3} \cdot \mathrm{dm}^{-3}$ and $313.0 \mathrm{mgCO}_{3}^{2 \cdot} \cdot \mathrm{dm}^{-3}$, respectively. As for average concentrations of the tested nitrogen forms (ammonia nitrogen, nitrite nitrogen, and nitrate nitrogen) they equaled $0.253,0.075$, and $0.302 \mathrm{mgN} \cdot \mathrm{dm}^{-3}$, respectively. Average concentrations of TRP, TP, and total iron amounted to $0.082,0.487 \mathrm{mgP} \cdot \mathrm{dm}^{-3}$ and $0.482 \mathrm{mg} \cdot \mathrm{dm}^{-3}$, respectively.

No high variability was discovered regarding water temperature and $\mathrm{pH}$ along the course of the river while analyzing horizontal variability. Lower DO concentrations were noted at sites 2 and 4 in comparison to the remaining sites. Organic matter concentration $\left(\mathrm{BOD}_{5}\right.$ and $\left.\mathrm{COD}_{\mathrm{Cr}}\right)$ was decreasing along the course of the river (Table 1). For those indicators the difference between sites 1 and 4 amounted to 1.0 and $14.0 \mathrm{mgO}_{2} \cdot \mathrm{dm}^{-3}$, respectively. Thus, obtained data indicated that along the studied stretch of the Ina River the drop in organic matter concentration amounted to ca. $25.0 \%$.

Average concentrations of total suspension at sites 1 and 2 were at the same level $\left(17.6 \mathrm{mg} \cdot \mathrm{dm}^{-3}\right)$, whereas at site
3 the concentration was $28.0 \%$ higher and at site 4 it equaled only $19.1 \mathrm{mg} \cdot \mathrm{dm}^{-3}$. A growth tendency along the course of the Ina River was noted for the following tested indicators: conductivity, alcalinity, total hardness, calcium ions, and chloride ions (Table 1).

Nitrate nitrogen dominated among the tested nitrogen forms; its average concentrations were higher than the concentrations of ammonia nitrogen and nitrite nitrogen by 0.049 and $0.227 \mathrm{mgN} \cdot \mathrm{dm}^{-3}$, respectively. A general growth tendency was discovered while analyzing horizontal variability of those indicators along the course of the river. Moreover, higher concentrations of ammonia nitrogen and nitrite nitrogen were noted at sites 2 and 4 in comparison to sites 1 and 3 . The difference in nitrate nitrogen concentrations in those two pairs of sites was exactly the opposite. As for ammonia nitrogen, its average concentration at site 2 was almost twice as high as at site 1 (average concentrations of ammonia nitrogen amounted to 0.324 and 0.176 $\mathrm{mgN} \cdot \mathrm{dm}^{-3}$, respectively). A drop in its average value was noted at site $3\left(0.235 \mathrm{mgN} \cdot \mathrm{dm}^{-3}\right)$, but it grew again at site 4 $\left(0.278 \mathrm{mgN} \cdot \mathrm{dm}^{-3}\right)$. Horizontal variabilities of TRP, TP, and iron concentrations were similar to horizontal variabilities noted for ammonia nitrogen and nitrite nitrogen (Table 1).

Furthermore, it was noted that the tested indicators were subject to seasonal changes. Maximum values of water temperature and total suspension concentration were noted in summer, whereas minimal values were noted in winter. As for DO, maximum concentrations were noted in winter and minimal ones in summer (Fig. 2). Also in summer, minimal values of $\mathrm{pH}$ were noted ( 7.3 on average). A summer drop in $\mathrm{pH}$ values followed the spring maximum for this indicator $(\mathrm{pH}=8.0)$. In autumn and winter average $\mathrm{pH}$ values equaled 7.8 and 7.7, respectively. Seasonal changeability of the studied biogenic elements was characterized by concentrations of nitrite nitrogen, ammonia nitrogen, TRP, and TP growing from winter till summer. A reverse tendency was reported for nitrate nitrogen (Fig. 3). Nitrate nitrogen variability was negatively correlated with $\mathrm{DO}$, whereas ammonia nitrogen variability was positively correlated with DO (Fig. 4).

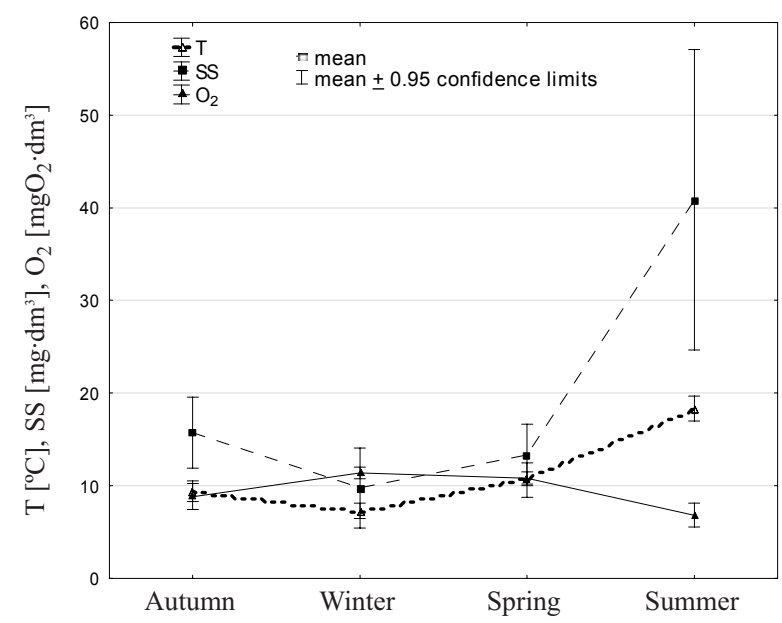

Fig. 2. Seasonal changes of water temperature, dissolved oxygen, and total suspension during studies conducted on the Ina River. 


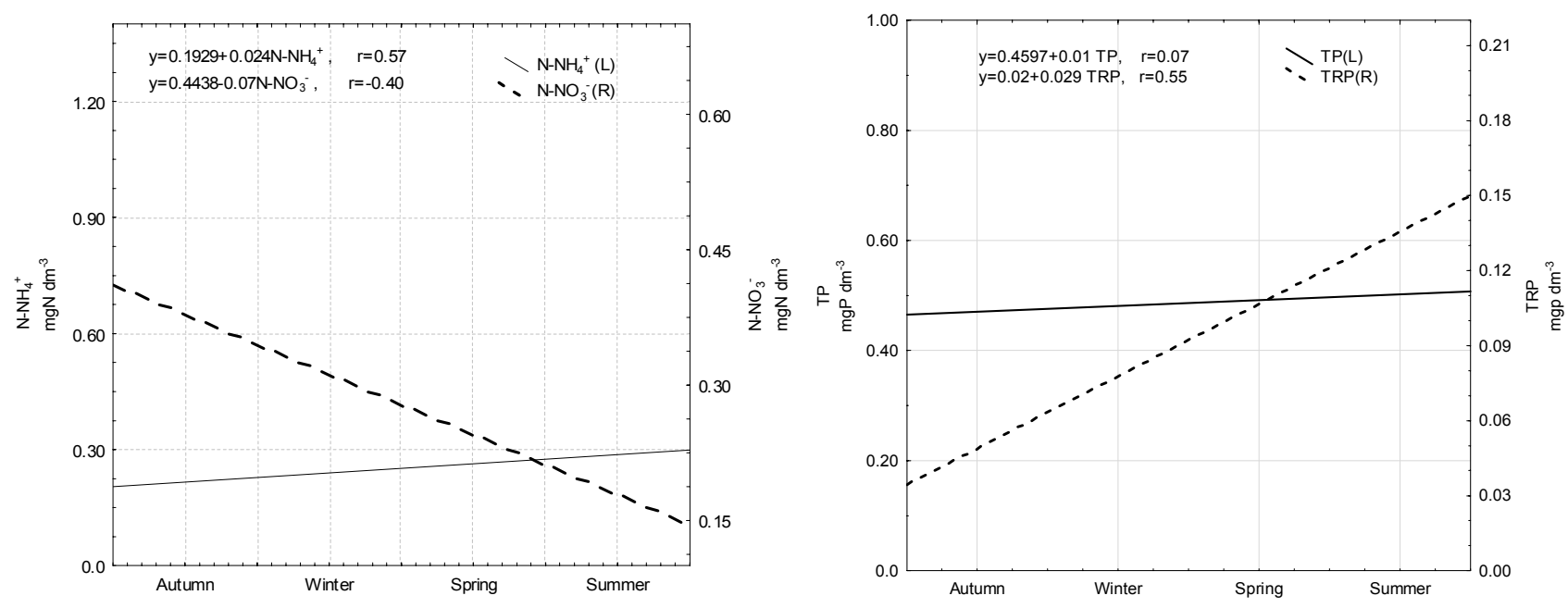

Fig. 3. A relationship between ammonia nitrogen, nitrate nitrogen, nitrite nitrogen concentrations, total reactive phosphorus (TRP), and total phosphorus (TP) on the one side and the season on the other.

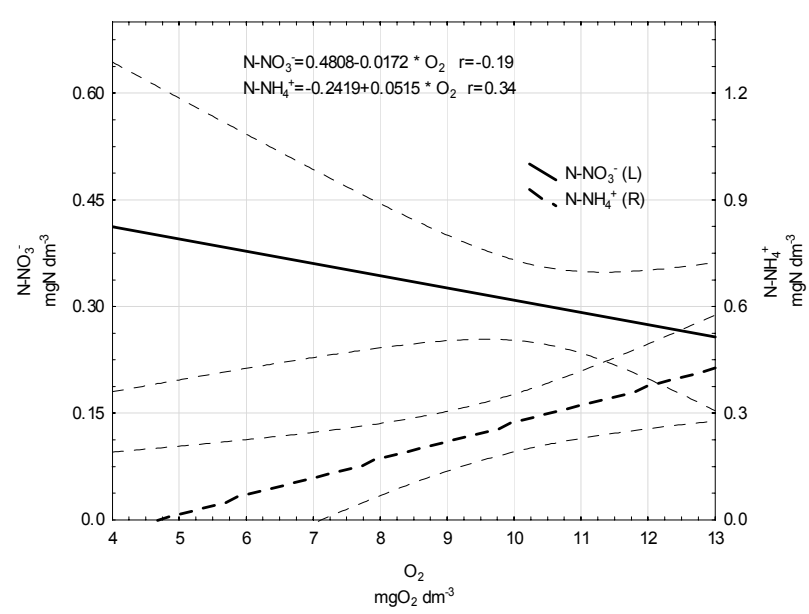

Fig. 4. A relationship between nitrate nitrogen and ammoniumnitrogen concentrations on the one side and dissolved oxygen concentration on the other.
Seasonal variability of the remaining indicators is shown in Fig. 5. It was determined that average conductivity values were decreasing from autumn till spring and then remained at the same level throughout the summer season. The lowest concentrations of chloride ions were noted in summer, whereas their highest concentrations were noted in winter. Furthermore, the lowest concentrations of calcium and magnesium were noted in spring and the highest were noted in summer. As for alcalinity, the lowest values were noted in winter and the highest values were noted in autumn.

The results of PCA analyses showed that four components accounted for about $74.092 \%$ of the total variance in the data matrix (Table 2). Component 1 was dominated by total hardness, calcium and magnesium ions, nitrite nitrogen and nitrate nitrogen, which accounted for $36.7 \%$ of the total variance. Component 2 was dominated by conductivity and ammonia nitrogen $(16.7 \%$ of the total variance).
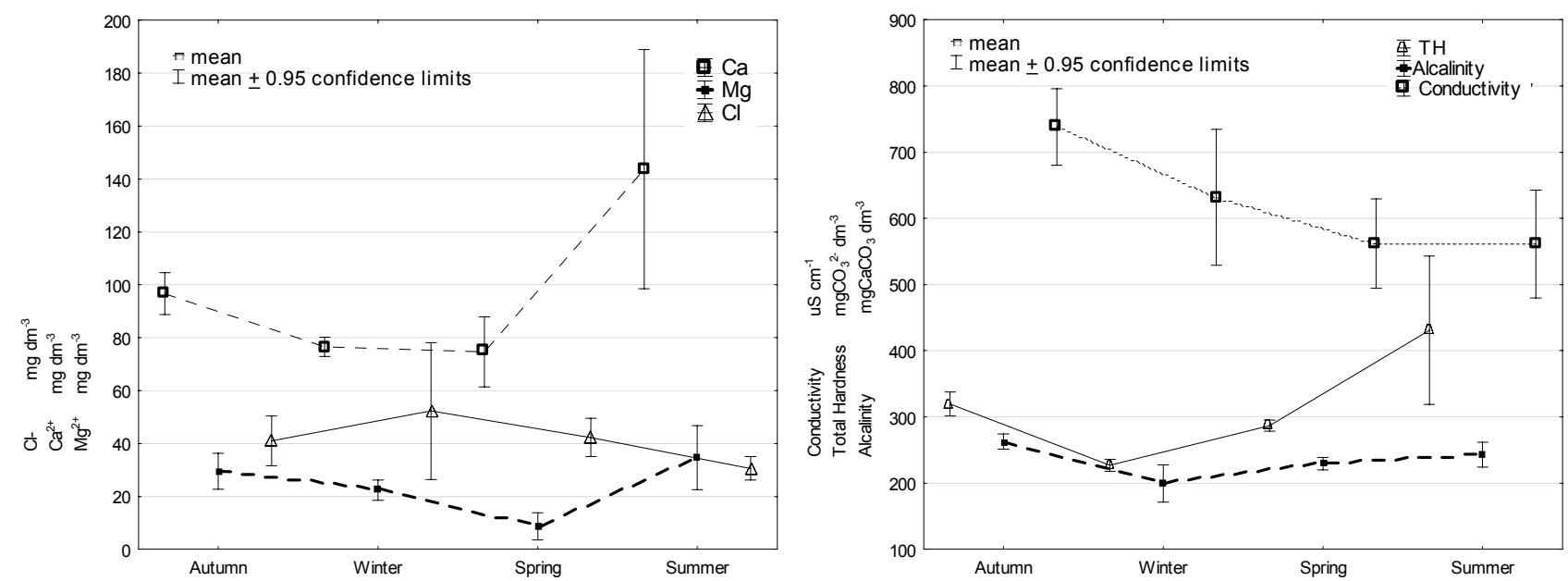

Fig. 5. Seasonal changes of conductivity, alkalinity, total hardness $(\mathrm{TH})$, calcium and magnesium ions, and chlorides during the studies conducted on the Ina River. 
Table 2. Component matrix and rotated component matrix varimax rotation (PCA extracted 4 factors).

\begin{tabular}{|c|c|c|c|c|c|c|c|c|}
\hline \multirow{2}{*}{ Parameters } & \multicolumn{4}{|c|}{ Rotated Component Matrix } & \multirow{2}{*}{ Components } & \multicolumn{3}{|c|}{ Initial eigenvalues } \\
\hline & 1 & 2 & 3 & 4 & & Total & $\%$ of Variance & Cumulative \% \\
\hline $\mathrm{T}$ & 0.629 & -0.219 & -0.484 & -0.013 & 1 & 6.598 & 36.7 & 36.7 \\
\hline $\mathrm{pH}$ & -0.783 & -0.166 & -0.222 & 0.268 & 2 & 2.997 & 16.7 & 53.3 \\
\hline SS & 0.499 & 0.188 & -0.390 & 0.010 & 3 & 2.165 & 12.0 & 65.3 \\
\hline $\mathrm{O}_{2}$ & -0.860 & 0.083 & 0.114 & -0.068 & 4 & 1.576 & 8.8 & 74.1 \\
\hline $\mathrm{BOD}_{5}$ & 0.138 & 0.250 & 0.021 & 0.780 & 5 & 1.454 & 8.1 & 82.2 \\
\hline $\mathrm{COD}_{\mathrm{Cr}}$ & -0.230 & -0.180 & -0.151 & 0.687 & 6 & 0.875 & 4.9 & 87.0 \\
\hline Conductivity & 0.032 & 0.693 & 0.036 & 0.167 & 7 & 0.697 & 3.9 & 90.9 \\
\hline Alcalinity & 0.376 & 0.364 & -0.627 & 0.290 & 8 & 0.442 & 2.6 & 93.4 \\
\hline $\mathrm{TH}$ & 0.853 & -0.386 & -0.108 & 0.024 & 9 & 0.328 & 1.8 & 95.2 \\
\hline $\mathrm{Ca}^{2+}$ & 0.853 & -0.270 & 0.130 & 0.042 & 10 & 0.212 & 1.2 & 96.4 \\
\hline $\mathrm{Mg}^{2+}$ & 0.799 & 0.039 & 0.266 & 0.141 & 11 & 0.173 & 1.0 & 97.3 \\
\hline $\mathrm{Cl}^{-}$ & -0.332 & -0.332 & 0.550 & 0.292 & 12 & 0.136 & 0.8 & 98.7 \\
\hline $\mathrm{N}-\mathrm{NH}_{4}^{+}$ & -0.542 & 0.544 & -0.182 & 0.282 & 13 & 0.112 & 0.6 & 98.7 \\
\hline $\mathrm{N}-\mathrm{NO}_{2}^{-}$ & 0.841 & -0.460 & 0.074 & -0.066 & 15 & 0.076 & 0.4 & 99.1 \\
\hline $\mathrm{N}-\mathrm{NO}_{3}^{-}$ & 0.783 & -0.467 & 0.156 & -0.035 & 15 & 0.067 & 0.4 & 99.5 \\
\hline TRP & -0.209 & -0.683 & -0.564 & 0.273 & 16 & 0.051 & 0.3 & 99.8 \\
\hline $\mathrm{TP}$ & -0.318 & -0.682 & 0.497 & 0.185 & 17 & 0.035 & 0.2 & 99.9 \\
\hline $\mathrm{Fe}$ & -0.637 & -0.425 & -0.517 & -0.085 & & & & \\
\hline
\end{tabular}

Component 3 was dominated by chloride ions and TP $(12.0 \%$ of the total variance), and finally component 4 was dominated by $\mathrm{BOD}_{5}$ and $\mathrm{COD}_{\mathrm{Cr}}(8.8 \%$ of the total variance).

It was reported that average annual values of $\mathrm{COD}_{\mathrm{Cr}}$, $\mathrm{TP}$, total hardness, and alcalinity did not meet the requirements set for class II water quality. Therefore, the quality of studied waters was less than good. As for average annual values of TRP and $\mathrm{BOD}_{5}$, they met the requirements set for class II water quality, whereas values of the remaining tested indicators classified the studied stretch of the Ina as class I water quality [9].

\section{Discussion}

Flow of water in rivers has a turbulent character, which entails high dynamics of water masses and homogeneity of water composition in vertical cross-section [2]. The lack of horizontal variability regarding temperature along the stretch of the Ina studied by us was caused by the turbulent water flow. Variability of that parameter depended solely on seasonal changes characteristic for temperate climate. This indicated that no warm wastewater that would cause a local temperature increase was discharged in the studied region, as was the case in the studies conducted, for example, by Nędzarek and Chojnacki [10] and Nędzarek and Tórz [11] near the mouth of the Oder River, where spent cooling water from the Dolna Odra Power Station in Nowe Czarnowo was discharged.

In the case of a river with chemical composition of water formed by the whole catchment area, it is a characteristic trend that concentrations of substances dissolved in water grow from the river source toward its mouth $[2,12]$. Such a trend was also noted in the course of our studies. However, fluctuations of average concentrations were observed from one research site to another with regard to several indicators. The fluctuations were noted, for instance, with respect to ammonia nitrogen, nitrite nitrogen, phosphorus, and iron. It allows us to suspect that wastewater was discharged in the neighborhood of the sampling sites (2 and 4), raising concentrations of those indicators in the water of the studied river. Those sites were located in the proximity of the factory specializing in agricultural production and processing food and agricultural produce (site No. 2) and near the town of Stargard Szczeciński (site No. 4). Simultaneously, tested concentrations of inorganic forms of nitrogen, TRP, and TP were very high.

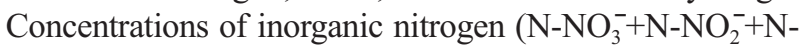
$\mathrm{NH}_{4}^{+}$), TRP and TP in rivers not subjected to anthropopres- 
sure does not exceed $0.120 \mathrm{mgN} \cdot \mathrm{dm}^{-3}, 0.010$ and 0.025 $\mathrm{mgP} \cdot \mathrm{dm}^{-3}$, respectively [13]. At the same time, ammonia nitrogen constitutes $15 \%$ of inorganic nitrogen, whereas nitrite nitrogen constitutes only $1 \%$. In our study we showed that average concentrations of those indicators, in comparison to concentrations given by Meybeck [13], were ca. 5 times higher for inorganic nitrogen, 8 times higher for TRP, and almost 20 times higher for TP. Percentage shares of ammonia nitrogen and nitrite nitrogen in inorganic nitrogen amounted to $40.0 \%$ and $12.0 \%$, respectively. Thus, the Ina River ought to be considered as a river subjected to strong anthropopressure. This fact has been confirmed by studies conducted by the Voivodeship Inspectorate for Environmental Protection [6, 7] as part of basic monitoring, classifying water quality in the Ina as good or less than good. Water quality evaluation conducted by us, performed according to the principles of monitoring currently in force [9], showed that factors declassifying the waters of the Ina River included $\mathrm{COD}_{\mathrm{Cr}}$, TP, total hardness, and alcalinity. Additionally, maximum noted values of other indicators (total suspension, $\mathrm{BOD}_{5}$, TRP) failed to meet even the border values of limits set for class II water quality. Thus it can be concluded that during the period when the research was conducted, the waters of the studied stretch of the Ina River were exposed to periodical and local pollution.

The availability of $\mathrm{N}$ and $\mathrm{P}$ in the studied river was conducive to an increase of the primary production, which was probably reflected by the increase of total suspension noted in the summer season. On the basis of the studies conducted by Kufel and Kufel [14] it could be assumed that in the total suspension determined by us, algae were also an important component.

In ecosystems characterized by high fertility, the paths along which such processes as ammonification, nitrification and denitrification are carried out, become distorted [15-17]. In our studies we noted an inversely proportional relationship between nitrate nitrogen and DO (Fig. 4), simultaneously with a negative and statistically significant correlation between that form of nitrogen and the season (Fig. 3). Such a negative correlation is connected with the fact that nitrate nitrogen is the major form of nitrogen absorbed by autotrophs. In the summer season, as a result of the process of ammonification (which was probably more effective due to higher temperature), ammonia nitrogen was released more intensely (correlation coefficient of that indicator with season was statistically significant: $r=$ 0.57). As a result of the lower DO level in the summer season and intense absorption of nitrate nitrogen by autotrophs, further changes of ammonia nitrogen led to the noted increase of only one nitrogen form in summer, namely nitrite nitrogen. Additionally, the phosphorus intensely released to the biocenosis (by live organisms as well as post mortem) was not completely absorbed by autotrophs, as was indicated by the proportional relationship between TRP and the season (Fig. 3), and the correlation coefficient was statistically significant: $r=0.55$. This is typical for water bodies of a high trophic status, where bio- and abiosestonic matter co-occurs with high concentrations of reactive phosphorus, which is not fully used by plants due to its excessive quantity [15]. According to Wetzel [2] or Rabalais [17], the above-discussed changes result in accumulation of biogenic elements in the ecosystem.

A characteristic feature of a river is its ability for selfpurification $[17,18]$. This process was noted in the studied stretch of the Ina River. It was indicated by the horizontal drop of DO combined with a drop in organic matter concentration as characterized by $\mathrm{COD}_{\mathrm{Cr}}$ and $\mathrm{BOD}_{5}$. The process of self-purification ought to be perceived in terms of a factor modifying changes and dynamics of nitrogen and phosphorus in the studied river and leading to the internal enrichment with biogenic elements. However, those processes are multi-directional and (even in light of the above attempt) still difficult to define explicitly. This was reflected by the conducted PCA analysis, where component 1 accounted for just $36.7 \%$ of the total variance and the total variance exceeding $90.0 \%$ was only noted for 7 components (Table 2).

Horizontal stability of calcium and magnesium concentrations, as well as comparatively stable water alcalinity are conditioned by high water bufferness, as indicated by total hardness and comparatively steady $\mathrm{pH}$ [19]. After Dickson [20] the waters of the Ina can be classified as resistant to acidification, since alcalinity of that type of waters does not exceed $75.0 \mathrm{mgCaCO}_{3} \cdot \mathrm{dm}^{-3}$. Maximum concentrations of calcium and magnesium noted by us in the summer season were connected with decomposition of bicarbonates; a drop in $\mathrm{pH}$ values was noted during that period $(\mathrm{Ca} / \mathrm{pH}$ correlation was statistically significant: $\mathrm{r}=-0.50$ ). Abundance of such metals as $\mathrm{Ca}^{2+}, \mathrm{Mg}^{2+}$, or $\mathrm{Fe}^{2+}$ in the Ina can affect phosphorus speciation. For instance, precipitation of phosphorus in the form of stable $\mathrm{Ca}_{5}\left(\mathrm{PO}_{4}\right)_{3} \mathrm{OH}$ increases by more than $60 \%$ when calcium concentration exceeds $50 \mathrm{mg} \cdot \mathrm{dm}^{-3}$. Reactive phosphorus is absorbed on the surface of precipitated calcium carbonate or magnesium carbonate. Also iron(II) hydroxide present in suspended particles or colloids is partially responsible for phosphorus adsorption. Those processes depend on the presence of dissolved oxygen and slightly heightened $\mathrm{pH}$ during the period when the process of intense photosynthesis is taking place [21-24]. Also in our studies we noted strong correlations between phosphorus and those metals. A statistically significant correlation between phosphorus and iron $(r=0.77)$ indicated that in well-oxygenated water of the studied river soluble iron(III) hydroxide was prevailing and there was no aggregation of phosphorus sedimentation. A summer increase in $\mathrm{Ca}^{2+}$ and $\mathrm{Mg}^{2+}$ concentrations was accompanied by an increase in TRP concentration. This relationship indicated that during summer, when water $\mathrm{pH}$ decreased $(\mathrm{pH}<8.0)$, the dynamics of carbonate equilibrium moved toward a drop in the share of carbohydrates and an increase of $\mathrm{CO}_{2}(\mathrm{aq})$, with a simultaneous release of reactive phosphorus.

The noted maximum of chloride ions at site no. 4 and their maximum concentration during winter indicated anthropopressure connected with the surface runoff of meltwater with an admixture of $\mathrm{NaCl}$ from road salt. 


\section{Conclusions}

During the period when the studies were conducted, the Ina River was subjected to strong anthropopressure. Indicators declassifying water quality included $\mathrm{COD}_{\mathrm{Cr}}, \mathrm{TP}$, total hardness, and alcalinity. The analysis of horizontal variability, especially N, P and Fe, revealed the presence of sources of pollution along the studied stretch of the river, located in the proximity of the factory specializing in agricultural production and processing food and agricultural produce as well as in the proximity of the town of Stargard Szczeciński.

The process of self-purification ought to be perceived as a factor modifying changes and the dynamics of biogenic elements as well as carbonate equilibrium, leading to an internal enrichment with nitrogen, phosphorus, iron, calcium and magnesium of the waters of the Ina River.

\section{Acknowledgements}

We would like to thank Mr. Artur Furdyna, president of the Friends Society of the Ina and Gowienica Rivers for his valuable advice and assistance with collecting water samples.

\section{References}

1. VANNOTE R.L., MINSHALL G.W., CUMMINS K.W., SEDEL J.R., CUSHING C.E. River continuum concept. Can. J. Fish. Aquatic Sci. 37, (1), 130, 1980.

2. WETZEL R.G. Limnology. Lake and River Ecosystems. Academic Press, 2001.

3. VITOUSEK P.M., MOONEY H.A., LUBCHENKO J., MELILLO J.M. Human domination of Earth's ecosystems. Science, 277, 494, 1997.

4. TAŃSKI A., BONISŁAWSKA M., SZULC J., BRYSIEWICZ A., FORMICKI K. Justifiability of establishing spawning grounds for migrating salmonid fish in the catchment area of the Ina River in light of environmental studies. Water-Environment-Rural Areas. 11, 3, (35), 253, 2011 [In Polish].

5. TAŃSKI A., FORMICKI K., BONISŁAWSKA M., KORZELECKA-ORKISZ A., WINNICKI A. Possibilities of supporting natural reproduction of the Atlantic salmon (Salmo salar L.) and the sea trout (Salmo trutta m. trutta L.) in the Ina River catchment basin. In: Biotechnology in aquaculture Eds. Z. Zakęś, J. Wolnicki, K. Demska-Zakęś, R. Kamiński, D. Ulikowski. IRS Olsztyn, pp. 173-180, ISBN 5.978-8360111-31-4, 2008 [In Polish].

6. VOIVODESHIP INSPECTORATE FOR ENVIRONMENTAL PROTECTION. WIOŚ. Report on environmental status in zachodniopomorskie province in the years 2008-2009. P. VI. 2. Rivers. Biblioteka Monitoringu Środowiska [online]. Szczecin. [Access 05.06.2013]. http://www.wios.szczecin.pl/bip/chapter_16003.asp?soid=9 909108BB3CB41938A7973DC9CE77170, 2011 [In Polish].

7. VOIVODESHIP INSPECTORATE FOR ENVIRONMENTAL PROTECTION. WIOŚ. Report on environmental sta- tus in zachodniopomorskie province in the years 2010-2012. P. II. 2. Rivers. Biblioteka Monitoringu Środowiska [online]. Szczecin. [Access 05.06.2013]. http://www.wios.szczecin.pl/bip/chapter_16003.asp?soid=99 D70A4564AB4E138390A7E3E22F9B65, 2013 [In Polish].

8. APHA. Standard Methods for Examination of Water and Wastewater. Am. Publ. Health Assoc., Washington. 1999.

9. DIRECTIVE OF THE MINISTER OF ENVIRONMENT of 9th November 2011 on classification of uniform parts of surface waters and on environmental quality standards for priority substances J. Law. 2011 No. 257 Item 1545, 2011 [In Polish].

10. NĘDZAREK A., CHOJNACKI J.C. Variability of selected hydrochemical parameters of the 3RD Order river Odra estuary in relation to hydrology of the area in 1997-2000, EJPAU, 6, (1), 01.

http://www.ejpau.media.pl/series/volume6/issue1/fisheries/ art-01.html, 2003.

11. NĘDZAREK A., TÓRZ A. The primary production of Tertiary estuary (Dąbie Lake, Poland). Limnol. Rev., 9, (1), 17, 2009.

12. GONG D., GAO X., NTAKIRUTIMANA T., GUO J., LI K. Water quality status along the Liangtan River and control planning alternatives for pollution reduction. Pol. J. Environ. Stud., 22, (4), 1061, 2013.

13. MEYBECK M. Carbon, nitrogen and phosphorus transport by world rivers. Am. J. Sci., 282, 401, 1982.

14. KUFEL I., KUFEL L. Eutrophication processes in a shallow, macrophyte-dominated lake - nutrient loading to and flow trough Lake Łuknajno (Poland). Hydrobiol., 342/343, 387, 1997.

15. HEIP C.H.R., GOOSEN N.K., HERMAN P.M., KROMKAMP J., MIDDELBURG J.J, SOETAERT K. Production and consumption of biological particles in temperate tidal estuaries. Oceanogr. Mar. Biol. Ann. Rev., 33, 1, 1995.

16. MEYBECK M. The global change of continental aquatic systems: dominant impacts of human activities. Water Sci. Technol., 49, (7), 73, 2004.

17. RABALAIS N.N. Nitrogen in Aquatic Ecosystems. Ambio, 31, (2), 102, 2002.

18. BEHREND H., KORNMILCH M, KOROL R., STRONSKA M., PAGENKOPF W.G. Point and diffuse nutrient emission and transports in the Odra Basin and its main tributaries. Acta Hydroch. Hydrob., 27, (5), 274, 1999.

19. NĘDZAREK A., TÓRZ A., STEPANOWSKA K. The influence of intensive fish nutrition on the quality of cooling waters. Oceanol. Hydrobiol. St., 38, (3), 51, 2009.

20. DICKSON W. Water acidification-effects and countermeasures. Summary document. Ecol. Effect of Acid Depos., Nat. Swedish Environ. Prot. Board - Report PM, pp. 267273, 1983.

21. SOBALLE D.M., KIMMEL B.L. A large-scale comparsion of factors influencig phytoplankton abdundance in rivers, lakes and impoundments. Ecology, 68, 1943, 1987.

22. JONES R.J. Phosphorus transformations in the epilimnion on humic lakes: Biological uptake of phosphorus. Freshwater Biol., 23, 323, 1990.

23. NOE G.B., CHILDERS D.L., JONES R.D. Phosphorus biogeochemistry and the impact of phosphorus enrichment: why is the Everglades so unique? Ecosystems, 4, 603, 2001.

24. ADEGOKE H.I., ADEKOLA F.A., FATOKI O.S., XIMBA B.J. Sorptive interaction of oxyanions with iron oxides: a review. Pol. J. Environ. Stud., 22, (1), 7, 2013. 